\title{
STUDI PENGOLAHAN NUGGET IKAN TENGGIRI (Scombridae commerson) SKALA RUMAH TANGGA
}

\author{
STUDY OF PROCESSING OF MACRO FISH NUGGET (Scombridae commerson) \\ HOUSEHOLD SCALE
}

\author{
Aripudin, Pola S.T. Panjaitan*, Liliek Soeprijadi, Elvi A. br. Sebayang \\ Politeknik Kelautan dan Perikanan Karawang, Jalan Lingkar Tanjungpura, Karangpawitan, Kecamatan \\ Karawang Barat, Kabupaten Karawang, Jawa Barat, Indonesia
}

Teregistrasi I tanggal: 31 Agustus 2021; Diterima setelah perbaikan tanggal: 29 September 2021; Disetujui terbit tanggal: 30 September 2021

\begin{abstract}
ABSTRAK
Ikan tenggiri (Scombridae commerson) mengandung omega-3 yang berperan dalam pembentukan sel saraf otak anak-anak. Ikan tenggiri memiliki nilai ekonomis tinggi yang dapat diolah menjadi produk nugget yang disukai oleh berbagai kalangan baik anak-anak dan orang dewasa. Pada proses pengolahan nugget ikan tenggiri dengan penambahan bahan tambahan dapat menjadikan produk nugget yang bertekstur kenyal. Bahan baku yang digunakan dilakukan pengujian organoleptik untuk mengetahui kualitas mutunya agar pada akhirnya dapat dihasilkan produk nugget yang memenuhi standar dan layak dikonsumsi oleh masyarakat. Pada pengujian organoleptik terhadap bahan baku diperoleh nilai rata rata 7,8 sehingga ikan tenggiri yang digunakan dalam pembuatan nugget layak dan memenuhi standar. Pada tahapan proses pembuatan nugget diperoleh rendemen yang berbeda pada setiap perlakuannya mulai dari penerimaan bahan baku sampai dengan pelumuran tepung panir sebagai salah satu bahan tambahan yang digunakan. Terhadap hasil akhir olahan produk nugget ikan tenggiri dilakukan pengujian sensori dengan hasil rata-rata 8 yang artinya layak untuk di konsumsi.
\end{abstract}

Kata kunci: Nugget ikan, rendemen, pengujian

\begin{abstract}
Mackerel (Scombridae commerson) contains omega-3 which plays a role in the formation of children's brain nerve cells. Mackerel has a high economic value that can be processed into nuggets that are favored by various groups, both children and adults. In the process of processing mackerel fish nuggets with the addition of additional ingredients, it can make nugget products that have a chewy texture. The raw materials used are carried out by organoleptic testing to determine the quality so that in the end it can produce nugget products that meet the standards and are suitable for consumption by the public. In organoleptic testing of raw materials, an average value of 7.8 was obtained so that the mackerel used in making nuggets was feasible and met the standards. At the stage of the process of making nuggets, different yields were obtained for each treatment, starting from receiving raw materials to coating breadcrumbs as one of the additional ingredients used. The final result of processed mackerel fish nuggets was carried out by sensory testing with an average result of 8 which means it is suitable for consumption.
\end{abstract}

Keywords: Fish nuggets, yield, testing

Korespondensi penulis:

*Email: polapanjaitan@ymail.com

DOI: http://dx.doi.org/10.15578/plgc.v2i3.10391 


\section{PENDAHULUAN}

Ikan akan mudah rusak jika tidak langsung di tangani secara langsung, cepat dan tepat dalam menjaga mutunya. Oleh sebab itu ikan sebagai bahan pangan perlu dilakukan penanganan yang baik sesuai ketentuan agar dapat menjadi suatu produk olahan pangan yang memiliki nilai tambah. Ikan tenggiri salah satu jenis ikan pelagis yang memiliki kandungan protein cukup tinggi yang bermanfaat bagi kesehatan tubuh manusia. Kandungan omega-3 yang ada berperan dalam pembentukan sel-sel saraf otak pada anak-anak dalam meningkatkan kecerdasan pada proses pertumbuhannya. Ikan pada umumnya tidak disukai terutama anak-anak, karena aroma yang khas, dan duri yang banyak di jumpai. Akan tetapi banyaknya variasi olahan dan rasa gurih dapat menarik perhatian dan digemari anak-anak khususnya anak-anak usia sekolah. Penggunaan bahan baku ikan tenggiri lebih banyak pada penyajian produk perikanan seperti, otak otak, bakso ikan, kaki naga, keong emas, nugget dan lain lain. Nugget ikan tenggiri terbuat dari daging giling yang dicetak dalam bentuk empat persegi dan dilapisi tepung berbumbu (battered dan breaded), (Maghfiroh, 2000).

Nugget ikan yang terbuat dari daging giling dengan penambahan bumbu yang menciptakan rasa gurih, sehingga tingkat kesukaan anak-anak pada ikan semakin tinggi. Nugget ikan tenggiri dapat menjadi makanan selingan (snack) dan dijadikan sebagai persediaan bahan makanan oleh ibu rumah tangga karena praktis dalam pengolahan dan aman untuk dikonsumsi (Prameswari et al., 2018). Selain itu, kemampuan pengolahan produk perikanan akan berkontribusi pada peningkatan pendapatan keluarga (Panjaitan, 2020; Prasetyati et al., 2021).

Ikan tenggiri yang bermutu dan segar dapat menciptakan suatu produk yang sehat, karena pasar dan juga konsumen pada umumnya akan memperhatikan dari aroma, rasa, bentuk, dan teksturnya. Tingkat kesegaran ikan sangat menentukan ikan yang digunakan sebagai bahan baku dalam proses pengolahan sekaligus menentukan nilai jual ikan (Surti \& Ari, 2004).

Studi bertujuan untuk mengetahui proses pengolahan nugget menggunakan bahan baku ikan tenggiri (Scombridae commerson) yang memenuhi persyaratan mutu organoleptik sehingga produk akhir nugget yang dihasilkan dapat memenuhi standar dan layak dikonsumsi oleh masyarakat.

\section{METODE PENELITIAN}

Waktu dan Tempat

Kegiatan studi dilakukan pada bulan Juli sampai dengan Agustus 2021 di Komplek Ruko Pasar Induk Blok D1/14. Jl Raya Bogor km 17, Jakarta Timur, DKI Jakarta.

\section{Bahan}

Bahan utama yang digunakan adalah ikan tenggiri (Scombridae commerson) yang diperoleh dari suplayer di Jakarta Utara. Bahan tambahan dan penolong diperoleh dari grosir di sekitar tempat kegiatan dilakukan, yang digunakan sebagai penambah cita rasa dan kekenyalan pada produk nugget.

\section{Metode Analisis}

Pengamatan mutu pada bahan baku dan produk akhir dilakukan secara langsung dan analisis data dilakukan menggunakan metode analisis deskriptif dengan menggambarkan data yang diperoleh sebagaimana adanya, (Soegiyono, 2017). Pengujian mutu bahan baku adalah dengan uji organoloptik meliputi, mata, insang, lendir, daging, bau, dan tekstur untuk mengetahui kesegaran bahan baku yang digunakan. Ikan tenggiri yang lolos 
penggujian maka digunakan sebagai bahan baku pembuatan nugget. Untuk pengujian produk akhir nugget dilakukan dengan uji hedonik atau uji tingkat kesukaan yang meliputi kenampakan, bau, rasa, dan tekstur.

Pengujian organoleptik bahan baku dan pengujian produk akhir nugget ikan tenggiri dilakukan oleh 6 panelis terlatih dengan 3 kali pengulangan pengujian untuk dapat lebih memaksimalkan hasil dengan menggunakan scoresheet organoleptik SNI 2729: 2013 untuk bahan baku dan SNI 7758: 2013 untuk produk nugget.

Untuk mengetahui hasil akhir olahan nugget dilakukan juga pengamatan terhadap rendemen produk akhir. Rendemen merupakan perolehan hasil melalui perbandingan antar bobot bahan yang dihasilkan dengan bobot bahan awal. Persentase rendemen dihitung dengan rumus, sesuai Pers. (1).

$$
\text { Rendemen }(\%)=\frac{\text { Bobot akhir }(\text { gram })}{\text { Bobot awal }(\text { gram })} \times 100 \%
$$

\section{HASIL DAN BAHASAN \\ HASIL}

Nugget Ikan Tenggiri

Proses pengolahan nugget ikan yang terbuat dari daging giling dan ditambahkan bahan pengikat dan bahan penolong, Untuk menjaga mutu dan memperpanjang daya simpan dapat dikukus atau digoreng setengah matang dan dibekukan untuk memperpanjang daya simpan produk nugget sehingga dapat digunakan dalam waktu yang lebih lama dan tetap pada penyimpanan yang terjaga dan terkontrol. Nugget ikan tenggiri merupakan olahan dari daging giling, dicetak berbentuk potongan empat persegi dan dilapisi tepung berbumbu (battered and breaded), (Syamsir, 2008). Nugget sebagai olahan setengah jadi masih memerlukan proses pengolahan lebih lanjut. Nugget dikonsumsi setelah melewati proses penggorengan, yang dapat memberikan rasa gurih, tekstur yang renyah dan kenyal (deep fat frying) (Saleh et al., 2002). Penggorengan merupakan proses pemasakan yang dilakukan menggunakan minyak atau lemak pangan. Bahan pangan yang digoreng mengalami perubahan pada permukaan luar dan berwarna coklat keemasan. Warna berubah karena reaksi pencoklatan (Maillard). Reaksi maillard terjadi antara protein, asam amino, dan amin dengan gula aldehida dan keton, yang merupakan penyebab terjadinya pencoklatan selama pemanasan atau penyimpanan dalam waktu yang lama pada bahan pangan yang berprotein.

\section{Komposisi}

Bahan-bahan dalam pembuatan nugget ikan tenggiri adalah; ikan tenggiri, tepung tapioka, garam, bawang putih, merica bubuk, penyedap rasa, tepung panir, telur, minyak sayur, air dan, batu es. Berikut adalah bahan-bahan yang di gunakan dalam pembuatan nugget ikan tenggiri, antara lain:
1). Daging ikan tenggiri $600 \mathrm{gr}$;
2). Tepung tapioka $300 \mathrm{gr}$;
3). Garam 10 gr;
4). Bawang putih $70 \mathrm{gr}$;
5). Merica bubuk 5 gr;
6). Penyedap rasa 5 gr;
7). Tepung panir 500 gr;
8). Telur 1 butir;
9). Minyak sayur $50 \mathrm{ml}$;
10). Air $10 \mathrm{ml}$;
11). Batu es 1 gelas. 


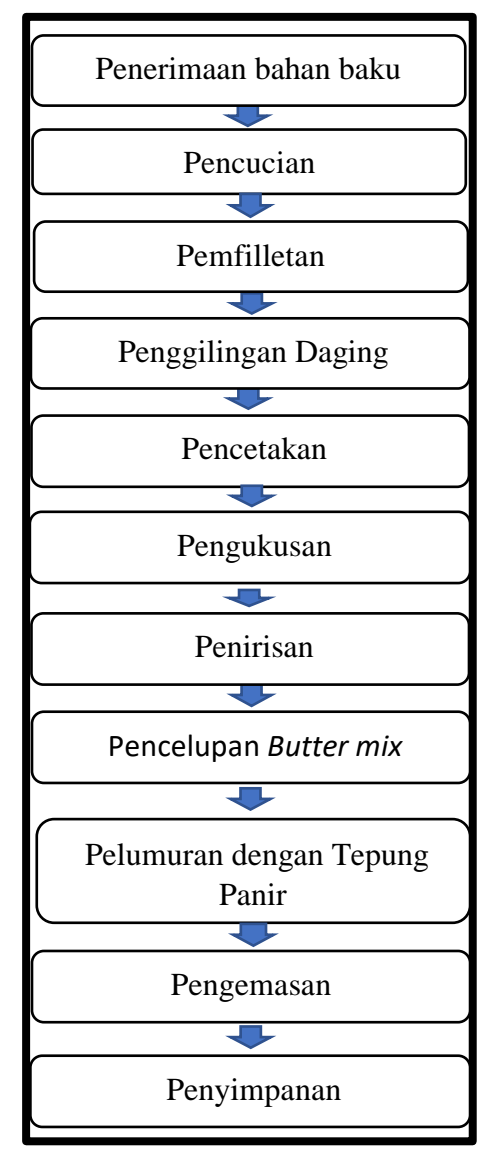

Gambar 1. Alur proses pengolahan nugget ikan tenggiri

Figure 1. Process flow of mackerel fish nuggets

\section{Penerimaan Bahan Baku}

Bahan baku pada proses pengolahan nugget yaitu ikan tenggiri yang di dapat dari Pelabuhan Perikanan Samudera "Nizam Zachman" Muara Baru, Jakarta Utara. Bahan baku yang di dapatkan dalam keadaan frozeen yang memenuhi persyaratan mutu. Ikan tenggiri di susun dalam Styrofoam untuk menjaga mutu dan suhu pada ikan agar tetap segar.

\section{Pencucian}

Bahan baku yang sudah di terima masuk pada proses pencucian untuk membersihkan ikan. Ikan ditangani secara teliti dan benar, pencucian menggunakan air mengalir untuk menghilangkan kotoran pada bahan baku ikan.

\section{Pemfilletan}

Proses pemfilletan dimulai dengan menyayat belakang sirip ikan hingga ke bagian kepala sampai pada penyayatan punggung. Pada proses pemfilletan ikan tenggiri dilakukan secara cepat dan tepat sehingga mutu pada ikan tetap terjaga. Fillet ikan yang dihasilkan adalah fillet ikan tanpa kulit dan tulang sehingga dapat mempermudah dalam proses penggilingan dan mendapatkan hasil yang baik.

\section{Penggilingan}

Fillet daging ikan tenggiri kemudian di giling sampai halus dengan tetap menjaga suhu pada daging dangan penambahan es secara berulang dalam proses penggilingan, tujuan dari penggilingan daging ikan untuk 
mempermudah pencampuran dan penyerapan antara bahan tambahan yang digunakan.

\section{Pencetakan}

Adonan yang telah selesai maka dilakukan pencetakan, untuk sebelumnya cetakan di lapis dengan minyak sayur tujuanya agar cetakan dan adonan tidak saling lengket dan mendapatkan hasil yang tidak cacat atau pun rusak. Adonan dicetak dan diratakan untuk mempermudah pemotongan. Adapun cetakan yang di gunakan adalah cetakan yang sering di pakai oleh produksi olahan pangan rumahan.

\section{Pengukusan}

Adonan yang telah di tuang kedalam cetakan, dilakukan proses pengukusan selama 20 menit. Ada pun tujuan dari menggunakan pengukus adalah untuk tetap mempertahankan kandungan gizi, protein dan lainya agar tidak hilang, karena proses pemasakan dengan uap setelah diangkat maka siap untuk ditiriskan.

\section{Penirisan}

Penirisan nugget ikan tenggiri yang dilakukan selama 20 menit untuk menurunkan kadar air pada nungget. Selama penirisan di ikuti dengan proses pendinginan, yang bertujuan untuk menjaga kesetabilan suhu pada produk sehingga pada penirisan dan pendinginan terjadi perubahan peningkatan kekenyalan seiring dengan penurunan kadar air.

\section{Pencelupan butter mix}

Nugget yang sudah tiris dan dalam keadaan dingin selanjutnya dilakukan proses pencelupan ke larutan butter mix. Untuk pembentukan kulit nungget sebelum dilakukan pencelupan ke tepung panir. Tujuanya adalah agar tepung panir menempel secara merata dan menambah rasa yang lebih gurih dari nugget ikan tenggiri.

\section{Pelumuran tepung panir}

Nugget yang telah di dicelupkan pada butter mix maka selanjutnya dilakukan pencelupan tepung panir secara merata. Sehingga bentuk nugget yang di hasilkan terlihat menarik, nugget merupakan olahan setengah jadi sehingga perlu dilakukan proses penggorengan sehingga tektur dan rasa lebih renyah dan gurih.

\section{Pengemasan}

Pengemasan adalah tahap akhir pengolahan nugget ikan tenggiri,yang bertujuan untuk melindungi produk dari kontaminasi silang yang dapat merusak produk. Kemasan yang digunakan yaitu plastik bening dimana pada plastik tersebut di berikan label produk untuk lebih dikenal lagi oleh konsumen. Setiap kemasan nugget berisi 15 potong dengan berat 200 gram.

\section{Penyimpanan}

Nugget yang telah dikemas maka dapat di simpan di frezeer dengan suhu $23^{\circ} \mathrm{C}$ agar daya simpan nugget ikan tenggiri lebih tahan lama dan tidak mengalami kerusakan. selama penyimpanan agar memperhatikan suhu pada produk.

\section{Pengujian Organoleptik Bahan Baku Ikan Tenggiri}

Bahan baku adalah ikan utuh beku yang sebelum dilakukan proses pengolahan terlebih dahulu dilakukan uji organoleptik. Yang diamati adalah mata, insang, lendir, daging, bau, dan tekstur. Penggujian dilakukan oleh 6 panelis dengan 3 kali pengulangan. 
Tabel 1. Hasil Pengujian Organoleptik Bahan Baku Ikan Tenggiri Table 1. Results of Organoleptic Testing of Mackerel Fish Raw Materials

\begin{tabular}{ccc}
\hline Pengamatan & Simpangan baku & Nilai Rerata \\
\hline 1 & $7,82 \leq \mu \leq 7,98$ & 8 \\
2 & $7.49 \leq \mu \leq 8,11$ & 7 \\
3 & $7,84 \leq \mu \leq 8,16$ & 8 \\
\hline
\end{tabular}

Hasil pengujian organoleptik nilai bahan baku ikan tenggiri yang terendah adalah 7 dan nilai yang teringgi adalah 8 . Nilai tersebut memenuhi persyaratan sesuai dengan SNI 2729: 2013 yang menunjukkan bahwa bahan baku ikan tenggiri layak untuk di gunakan sebagai bahan baku pembuatan nugget ikan tenggiri.

\section{Pengujian Hedonik Produk Nugget Ikan Tenggiri}

Produk akhir dilakukan uji hedonik atau uji tingkat kesukaan untuk mengetahui layak atau tidaknya produk tersebut untuk di konsumsi. Pengujian dilakukan dengan mengamati produk akhir nugget ikan tenggiri yang meliputi kenampakan, bau, rasa, dan tekstur. Pengujian dilakukan oleh 6 panelis dengan 3 kali pengulangan.

Hasil pengujian hedonik produk akhir nugget ikan tenggiri berada pada nilai 7 untuk yang terendah dan nilai 8 untuk yang tertinggi. Nilai yang diperoleh tersebut memenuhi persyaratan sesuai dengan SNI 7758: 2013, dan nugget ikan tenggiri yang dihasilkan layak untuk di konsumsi.

Tabel 2. Hasil Pengujian Hedonik Nugget Ikan Tenggiri

Table 2. Results of Hedonic Testing of Mackerel Nuggets

\begin{tabular}{ccc}
\hline Pengamatan & Simpangan baku & Nilai Rerata \\
\hline 1 & Hasil $=7,29 \leq \mu \leq 8,51$ & 7 \\
2 & Hasil $=7,88 \leq \mu \leq 8,12$ & 8 \\
3 & Hasil $=7,79 \leq \mu \leq 8,01$ & 8 \\
\hline
\end{tabular}

\section{Rendemen}

Pengamatan rendemen pada proses pengolahan nugget ikan tenggiri dilakukan pada setiap tahapan untuk mengetahui pengurangan atau penambahan selama proses produksi sehingga dapat diketahui besaran rendemen yang dihasilkan pada produk akhir dengan adanya penambahan bahan tambahan dan bahan penolong yang digunakan. Rendemen akhir proses pengolahan nugget ikan tenggiri dapat di lihat pada Gambar 2.

\section{BAHASAN}

Uji Organoleptik Ikan Tenggiri

Hasil uji organoleptik sebagaimana pada Tabel 1, nilai yang tertinggi dari mata, insang, lendir, daging, bau, dan tekstur adalah pada pengamatan ke 3 (tiga) dengan nilai simpangan baku 7,84 $\leq \mu \leq 8,16$ dan nilai organoleptik yang diperoleh adalah 8 yang lebih di sukai oleh panelis. Hasil penilaian panelis terhadap bahan baku ikan tenggiri segar menunjukkan bahan baku memiliki kualitas baik dan memenuhi standar penggunaan bahan baku. Pengujian organoleptik merupakan uji oleh panelis mengenai sifat atau kualitas suatu bahan yang menyebabkan orang menyenangi (Afrisanti, 2010; Soekarto, 1990). Uyunun et al. (2020), melakukan uji organoleptik produk abon ikan pada salah satu unit UMKM di Banda Aceh, dan memperoleh penilaian 9, untuk masingmasing penilaian sensori penampakan, bau, rasa, dan tekstur. 


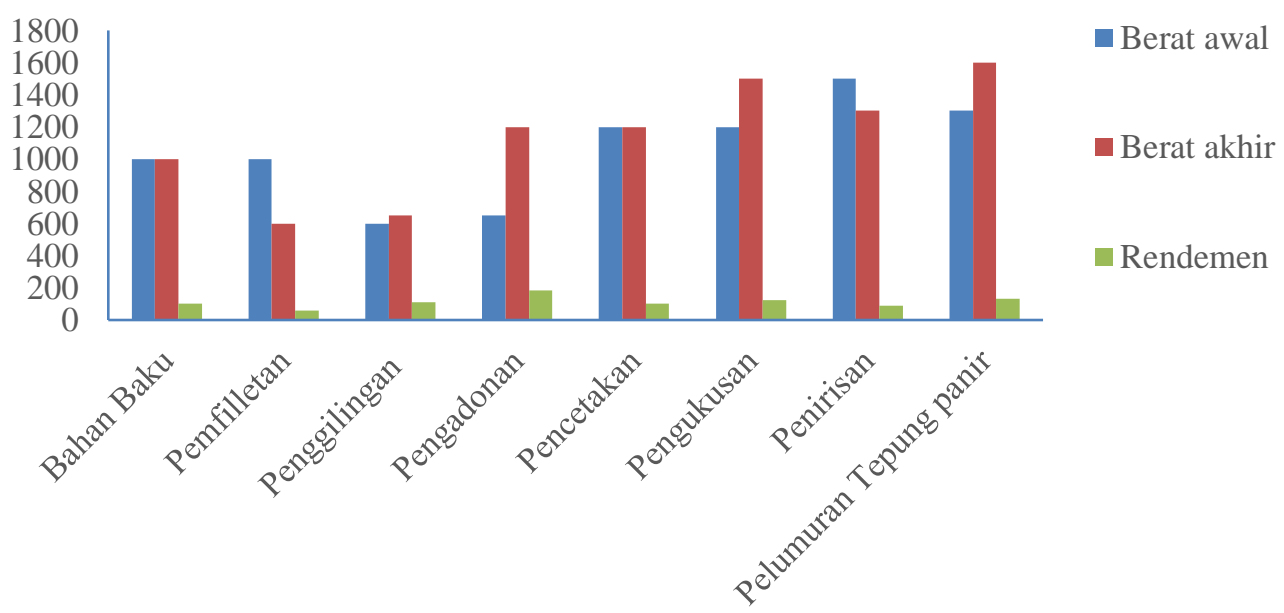

Gambar 2. Rendemen proses pengolahan nugget ikan tenggiri.

Figure 2. The yield of mackerel fish nuggets processing.

\section{Uji Hedonik Nugget Ikan Tenggiri}

Pada pengujian hedonik nugget ikan tenggiri dilakukan dengan indra manusia untuk menentukan tingkat kesukaan terhadap produk nugget ikan tenggiri yang diuji mulai dari kenampakan, bau, rasa, dan tekstur. Dari uji yang dilakukan maka nilai yang tertinggi adalah pada pengamatan ke-2 (dua) dengan nilai simpangan baku 7,88 $\leq \mu \leq 8,12$ dan nilai uji hedonik yang diperoleh adalah 8 (delapan). Hasil penilaian panelis terhadap produk nugget ikan tenggiri menunjukkan produk nugget disukai dan layak untuk dikonsumsi. Nugget ikan tenggiri merupakan makanan olahan siap saji yang berbahan baku dari lumatan daging ikan. Produk nugget berupa restructured meat dengan rasa dan aroma yang khas yang dipadu dengan tepung, telur, bumbu, dan kemudian diselimuti tepung panir, sehingga rasanya diminati oleh berbagai kalangan.

Beberapa kajian sebelumnya, dilakukan uji hedonik tekstur terhadap nata de seaweed (Gracilaria sp.) dengan penambahan ekstrak nanas, diperoleh nilai 7 (Sya et al., 2020); sosis ikan bandeng (Chanos chanos) dengan penambahan Gracilaria sp. memberikan nilai uji hedonik lebih tinggi dibandingkan tanpa penambahan (Permadi et al., 2020). Sementara, penambahan agar strip (Gracilaria sp.) pada pembuatan dodol jelly, meningkatkan nilai uji hedonik untuk parameter warna (Tanjung et al., 2020).

\section{Rendemen}

Pengamatan rendemen terhadap naget ikan tenggiri dilakukan pada setiap alur proses dan menunjukkan hasil yang berbeda pada tiap tahapan. Pengamatan bertujuan untuk mengetahui penambahan dan pengurangan setiap kali perlakuan dan hasil akhir dari produk nugget ikan tenggiri yang dihasilkan. Rendemen bahan baku mengalami penurunan pada proses pemfilletan, penirisan, Sedangkan pada pengadonan, pengilingan, pengukusan,pencelupan butter mix, dan penambahan tepung panir terjadi penambahan berat dari 1.000 gram dan berat produk akhir meningkat menjadi 1.600 gram. Semakin besar rendemen maka semakin tinggi nilai ekonomis atau keefektifan suatu bahan yang digunakan, Yunizal et al. (1998). 


\section{SIMPULAN}

Pengamatan terhadap bahan baku ikan tenggiri yang digunakan untuk membuat produk nugget memenuhi standar bahan baku dengan nilai rerata 8 dan layak digunakan sebagai bahan baku pada pengolahan nugget ikan tenggiri. Produk nugget ikan tenggiri yang dihasilkan diamati tingkat kesukaannya memiliki nilai rerata 8 dan layak untuk dikonsumsi. Hasil akhir produk nugget ikan tenggiri memiliki rendemen sebesar $160 \%$ yang dapat memberikan nilai ekonomis lebih tinggi.

\section{DAFTAR PUSTAKA}

Afrisanti, D. W. (2010). Kualitas kimia dan organoleptik nugget daging kelinci dengan penambahan tepung tempe. Program Studi Peternakan Fakultas Pertanian. Universitas Sebelas Maret. Surakarta.

[BSN] Badan Standar Nasional Indonesia. (2013). SNI 01-27292013 Ikan Segar. Jakarta: Badan Standar Nasional.

(2013). SNI 017758-2013 Naget Ikan. Jakarta: Badan Standar Nasional.

Maghfiroh, I. (2000). Pengaruh penambahan bahan pengikat terhadap karaktristik nugget dari ikan patin (Pangasius hypothalamus). Skripsi. Program Studi Teknologi Hasil Perikanan. Fakultas Perikanan Institut Pertanian Bogor. Bogor.

Panjaitan, P.S.T. (2021). Persepsi Wanita Pesisir terhadap Manfaat Pelatihan Pengolahan Hasil Perikanan dalam Meningkatkan Pendapatan Keluarga. PELAGICUS, 2(1), 1522.

Permadi, A., Wulansari, D., Tanjung, A., Aripudin. (2020). Pengaruh Penambahan Gracilari sp. terhadap Mutu Sosis Ikan Bandeng (Chanos chanos). PELAGICUS, 1(2), 63-70.
Prameswari, D., \& Andjarwati, A. L. (2018). Pengaruh Kualitas Layanan Jasa Terhadap Word Of Mouth dengan Kepuasan Pelanggan sebagai Variabel Antara (Studi pada Biro Perjalanan Umum Rosalia Indah Surabaya). BISMA: Jurnal Bisnis dan Manajemen, 3(1), 49-65.

Prasetyati, S.M., Permadi, A., \& Taryoto, A.H. (2021). Analisis Adopsi Teknologi Pembuatan Petis dari Limbah Pengolahan Pindang di Kabupaten Sukabumi. PELAGICUS, 2(2), 95-106.

Saleh, M., K. Prana, S. Hartatik. (2002). Dokumen Tepat Guna. Institut Pertanian Bogor. UPT. Perpustakaan. Bogor: Institut Pertanian Bogor.

Surti, T., \& Ari, W. (2004). Kajian terhadap Indeks Kesegaran secara Kimiawi pada Ikan Berdaging Merah dan Berdaging Putih. Laporan Akhir. Universitas Diponegoro. Semarang.

Syamsir , E. (2008). Panduan Praktikum Pengolahan Pangan. Departemen Ilmu dan Teknologi Pangan. Fateta IPB. Bogor. Hal : 24-25.

Sya, G.F., Permadi, A., \& Adi, C. P. (2020). Perbedaan Pengaruh Penggunaan Ekstrak Nanas dan Diamonium Fosfat terhadap Mutu Nata De Seaweed (Gracilaria sp.). PELAGICUS, 1(1), 1-10.

Soekarto, S. T. (1990). Penilaian Organoleptik untuk Industri Pangan dan Hasil Pertanian. Bhatara Karya Aksara. Jakarta.

Soegiyono, (2017). Metode Penelitian Kuantitatif, Kualitatif, dan $R \& D$. Bandung: Alfabeta, CV.

Tanjung, A., Saputra, R.S.H., Prasetyawati, S.B., \& Adi, C.P. (2020). Pembuatan Dodol Jelly dengan Penambahan Agar Strip (Gracilaria sp.) di Kabupaten Karawang. PELAGICUS, 1(3), 115-122. 
PELAGICUS: Jurnal IPTEK Terapan Perikanan dan Kelautan

Volume 2 Nomor 3: 167-175, September 2021

Yunizal, Suparno, \& Nasran, S. (1998). Usaha mengurangi kadar urea daging cucut mentah dengan perebusan menggunakan superheated steam. Laporan

Uyunun, Yuliana, E., \& Nurilmala, M. (2020). Analisis Prospektif Usaha Abon Ikan (Kasus: CV. Aroma Penelitian Teknologi Perikanan 28: Food, Kota Banda Aceh). 27-30. PELAGICUS, 1(3), 123-134. 